John Godbehere ‘Джон Боже будь здесь' (1456), Gilbert Godbiemidus 'Гильберт Боже будь с нами' (1219), Pardee, Pardew, Depardieux (<de par Dieu < лат. de parte Dei 'ради Бога').

«Набор» христианских ассоциаций в английских фамилиях свидетельствует о заметном месте, которое занимали клирики в средневековом английском обществе, и о роли церковного календаря, регулировавшего многие стороны жизни этого общества.

Reaney P. H. The Origin of British Surnames. London, 1980.

DOI 10.31168/7996-2700-3.2

\author{
Е. П. Андреева \\ Вологда, Россия \\ ep-andreeva@bk.ru
}

Вологодский государственный университет

\title{
Отражение архаических представлений о смерти в лексике вологодских говоров
}

По мнению О. А. Седаковой, «обращаясь к погребальной и поминальной обрядности и к тому кругу представлений, которые она выражает (смерть, жизнь, бессмертие, душа, доля, предки, “тот” и “этот” свет), мы касаемся самой сердцевины традиционной славянской культуры» [Седакова, 2004, 17].

Согласно данным вологодских говоров, народный ритуал погребения, с одной стороны, основан на православных традициях, с другой стороны, отражает дохристианские представления о смерти. Так, на территории Вологодской области широко распространен устойчивый оборот хороня́ть с ви́ носом 'хоронить по христианским обычаям, со священником’: «Если свяще́нник быў на похорона́х, то это называ́ли хороня́ть с вы́носом» (Влгд.) [СВГ, 1, 205]. Согласно православному обряду, на лоб умершего возлагается венчик, в руки покойного вкладывается текст с разрешительной молитвой. О соблюдении этой традиции свидетельствуют слова вено́к, подоро́жная 'венчик на лоб покойника': «Про́пуск в ру́ки подаю́т, а на ло́б накла́дывают вено́к» (Тот.); «Пре́жде (C) Андреева Е. П., 2019 
на ло́б поко́йнику накла́дывали подоро́жную» (Межд.) [СВГ, 8, 91; 7, 104]. Для обозначения понятия 'бумага с текстом молитвы, вкладываемая в руки покойного' в вологодских говорах используются слова похоронная, пропуск: «Ло́жили поко́йника в гро́б. Ложи́ли ему в ру́ки похоро́нную, лист с те́кстом моли́твы» (Гряз.) [СВГ, 8, 24].

Интерес представляет история лексемы подоро́жная. В словаре Даля это слово фиксируется без помет в значениях 'открытый лист на получение почтовых лошадей', 'разрешительная молитва по усопшем: местами она кладется в гроб’ [Даль, 3, 190]. СРНГ [28, 121] отмечает его в значениях: 1) 'написанная на листе бумаги молитва, которую вкладывают в руки усопшего’ (нижегор., перм., смол.); 2) ‘венчик на лоб покойника' (новг.). Видимо, со временем происходит контаминация понятий 'венчик' и 'разрешительная молитва', что приводит к изменению значения влг., новг. подоро́жная.

По церковным канонам подготовка к смерти предполагает заботу о душе умирающего. С крестьянской точки зрения, необходимо заранее позаботиться о вещественной стороне похорон: «Ста́рый я совсе́м, на́до уж и к сме́рти подгото́вицця. Да я́ уж и домови́ну себе́ построи́л, и крест смастери́л, и огра́ду сде́лал» (Верх.) [КСВГ]. Влг. дом, домови́на, домови́mе 'гроб' связаны с архаичной славянской мифологемой «гроб - дом умершего» [СД, 1, 553]. Заранее готовилась и погребальная одежда, о чем свидетельствуют устойчивые обороты сме́ртная оде́жда, сме́ртный у́зел: «Умру́, так смотри́, где у меня́ сме́ртной у́зёў лёжи́т» (Тарн.) [СВГ, 10, 55]. На базе отмеченных сочетаний образуется универбат сме́ртная: «Мы с де́дом уже́ приготовля́ем сме́ртную-то, чтоб, когда умрём, всё гото́во бы́ло» (Влгд.) [Там же].

Народные представления о связи живых с миром мертвых отражают контексты, иллюстрирующие значения слов бла́знить (ся), мала́вить, мала́нить 'чудиться, мерещиться, казаться', побла́знить, nомани́ть: «Бла́знилось мне, что муж поко́йный здесь стои́т, как живо́й, и есть про́сит» (У-Куб.) [КСВГ]. М. Н. Власова отмечает, что «по распространенным представлениям, покойные родственники, предки не исчезают бесследно, но продолжают “жить”, участвуя в делах семьи, крестьянской общины» [Власова, 1995].

Комментария требует внутренняя форма устойчивого оборота отда́mb пла́mьиųe 'умереть’: «Она́ и девети́ ме́сецей по́сле его́ не прожила́, то́жо пла́тьицо отдала́» (Сямж.) [СВГ, 7, 88]. 
Фразеологический образ, формирующий это значение, отражает народную традицию: отдавать вещи покойника тем, кто провожает его в последний путь. Об этом обычае свидетельствует и фразеологизм дары́ поко́йника 'вещи покойника, которые на поминках дарили пришедшим’. Казалось бы, отмеченная традиция соответствует христианским канонам: получивший милостыню должен молиться об умершем. Но в этом ритуальном действии можно увидеть и отголоски языческих верований, согласно которым существует постоянная связь между живыми и мертвыми членами рода. Отметим и фразеологизмы, свидетельствующие об обязанности живых обеспечить умершего в загробной жизни: купи́mь ме́сто 'об обычае класть монеты поверх крышки гроба на похоронах’, окупа́ть гроб (моги́лку) 'об обычае бросать в открытую могилу монеты' [КСВГ].

В связи с этим интерес представляет употребление влг. прах в значении 'нечистая сила': «Везде́ пра́х выгоня́л де́вку-то» (Шексн.) [СВГ, 8, 34]. Л. П. Якубинский, описывая распространение церковнославянизмов в говорах, рассматривает слово прах как эвфемизм черта [Якубинский, 1953, 116-117]. Действительно, в вологодских говорах фразеологизмы с компонентом прах (например, надава́ло ко праха́м (кого) 'о том, кто пришел не вовремя, некстати') строятся в основном по общерусским моделям с компонентом черт: пойти́ ко праха́м пойти к черту (ко всем чертям), прах но́гу сло́мит — черт ногу сломит. Но внутренняя форма этих фразеологизмов может сохранять и более ранние (дохристианские) представления наших предков о мире. Производное значение ст.-слав. прахъ 'останки, то, что осталось от тела умершего’ дает возможность предположить метонимический перенос значения ('останки' $\rightarrow$ 'сам умерший’). По словам С. М. Толстой, в отношениях мира живых и мертвых наряду с культом предков «явно присутствует страх перед мертвыми, сознание зависимости от них» [Толстая, 2000, 14]. Отчасти этим объясняется пейоративная окраска фразеологизмов с компонентом прах и дальнейшее развитие его семантики: 'умерший' $\rightarrow$ 'нечистая сила'.

Существовали магические действия, помогающие защититься от покойника, преодолеть страх перед ним: «По́сле похоро́нья стол, где поко́йник лежа́ў, прокида́ют, и на стол сади́тся тот, кто бои́тся» (Межд.) [СВГ, 8, 83]. Обрядовое действие переворачивания предметов при погребении описано Н. И. Толстым [1995]. 
В докладе рассматриваются также архаические мифологемы, сохранившиеся в вологодских говорах: «смерть - дорога» (про́nуск, подоро́жная, похоро́нная, на пра́вом пути́, непу́тной поко́йник), «смерть - сон, покой» (высыпа́льня, осыпа́льня, поко́йницкая), «гробдом» (дом, до́мик, домови́на, домови́ще).

Власова М. Н. Новая АБЕВЕГА русских суеверий. СПб., 1995. URL: http:// rumagic.ucoz.ru/files/abevega.

Даль В. И. Толковый словарь живого великорусского языка : в 4 т. М., 2006.

КСВГ - картотека «Словаря вологодских говоров» (хранится на кафедре русского языка, журналистики и теории коммуникации ВоГУ).

СВГ - Словарь вологодских говоров : в 12 т. / под ред. Т. Г. Паникаровской. Вологда, 1983-2007.

СД - Славянские древности : этнолингв. словарь : в 5 т. / под общ. ред. Н. И. Толстого. М., 1995-2012.

Седакова О. А. Поэтика обряда. Погребальная обрядность восточных и южных славян. М., 2004.

СРНГ - Словарь русских народных говоров / гл. ред. Ф. П. Филин (вып. 1-22) ; Ф. П. Сороколетов (вып. 23-42) ; С. А. Мызников (вып. 43-). М. ; Л. ; СПб., 1965-. Вып. 1-.

Толстая С. М. Мир живых и мир мертвых: формула сосуществования // Славяноведение. 2000. № 6. С. 14-20.

Толстой Н. И. Переворачивание предметов в славянском погребальном обряде // Толстой Н. И. Язык и народная культура: Очерки по славянской мифологии и этнолингвистике. М., 1995. С. 213-222.

Якубинский Л. П. История древнерусского языка. М., 1953. 